\title{
Konsep Dasar Manusia Menurut Islam Tinjauan Sosial Budaya
}

\author{
Oleh : Amir Mu'allim
}

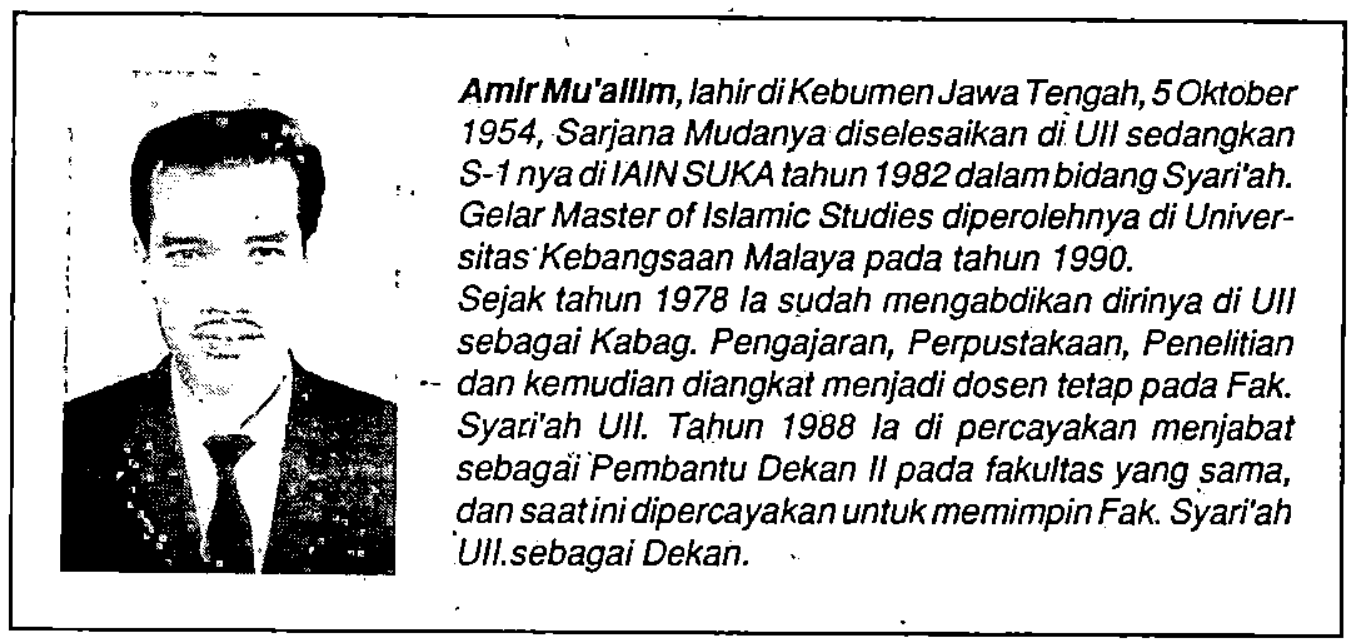

Pendahuluan

Kehidupan manusia di muka bumi ini senantiasa dihadapkan dengan berbagai masalah. Salah satu permasalahan yang selalu menjadi perhatian manusia terutuma yang berhubungan dengan Islam adalah masalah sosial budaya, karena dari sinilah munculnya keberágaman nilai yang berkaitan dengan perilaku manusia.

Dalam agama Islam masalah sosial budaya bukan merupakan hal yang asing, karena Islam tidak-sekedar agama yang mengajarkan tata cara kontemplasi ritual melainkan merangkum aspek ajaran yang meliputi aktivitas individu dan aktivitas sosial termasuk di dalamnya masalah budayà yang berkembang di masyarakat.

Istilah sosial budaya dalam tulisan ini diarahkan pada segala sesuatu yang terkait dengan kehidupan manusia dalam. dimensi sosial yang diperoleh dari hasil kajian dan kreativitas. Sedangkan hubungannya dengan umat Islam adalah merupakan prestasi dan kreasi manusia (muslim) yang dalam wujud operasionalnya bersumber dari ajaran pokok yaitu AlQur'an dan As-Sunnah.

Keberagaman budaya umat Islam harus didekatkan dan dapat diukur dengan nilai-nilai yang agung yang digali dari penghayatan, pemahaman dan pengalaman ajaran Islam. Nilai-nilai inilah yang kemudian menjadi landasan makhluk berbudaya yaitu manusia. Namun sebagai konsèkwensi dari globalisasi yang sudah merambah kepermukaan bumi, tiḍak menutup kemungkinan nilai-nilai budaya produk manusia akan menggeser nilai-nilai ilahiyah.

Bertitik tolak dari persoalan tersebut, tulisan ini mencoba mengungkap tentang ajaran Islam kaitannya dengan 
aspek sosial budaya hubungannya dengan perkembangan zaman.

\section{Pluralisme Kehidupan Manusia.}

Islam merüpakan norma yang harus menjadi acụan dalam mengaplikassikan perilaku manusia. Kapasitas produk perilaku manusia ditentukan oleh sejauh mana manusia mampu melekatkan kaidah/ norma Islam dalam dirinya.

Al-Qur'an telah menegaskan dalam kalimat yang pendek tapi berdimensi luas bahwa, kualitas manusia yang dikatakan "ashabul jannah" (penghuni sorga) adalah mereka yang memiliki pendalaman aqidah dan beramal saleh (al-A'raf : 42). Istilah lain yang melengkapi kualitas sumberdaya manusia adalah kemampuan seseorang dalam memadukan antara konsep pikir dan zikir (Ali Imron : 191).

Dalam kontek ini konsep pikir ménjadi perhatian dan bahasa. Konsep pikir seperti yang ditegaskan dalam surat Ali Imron ayat (9) adalah menjabarkan segala isi langit dan bumi dalam bentuk kreasi yang dapat memenuhi hajat hidup manusia yang berdaya guna dan berhasil guna. Ketinggian nilai aqidah seseorang adalah sangat didukung oleh kemampuan menggunakan nadhar (akal pikiran) dengan melihat ciptaan Allah secara makro. Keunikan alam dan pluralisme segala kehidupan manusia selalu dikembalikan kepada keagungan Rabbnya yang menciptakan alam, dengan kata-kata "Ya Tuhan kami, tiadalah Engkau menciptakan ini dengan sia-sia maha Suci Engkau, maka peliharalah kami dari siksa neraka" (Ali Imron : 191).

Al-Qur'an menegaskan bahwa. pluralisme hidup bermasyarakat adalah merupakan fithrah untuk memberikan kesempatan' kepada "hambanya berkompetisi dalam kebaikan (Al-Maidah : 48). Bagi orang Islam hidup dalam kemajemukan merupakan kesempatan untuk mengüji kemampuan dirinya dalam mengemban amanah Allah dengan mengingat batas-batas/norma yang ada. Allah menegaskan bahwa sikap hidup yang sehat itu adalah menggunakan segi-segi kelebihan masing-masing untuk secara maksimal saling mendorong dalam usaha mewujudkan berbagai kebaikan (Al khairat) dalam masyarakat:

Kemajemukan hidup dalam masyarakat tidak sekedar tertulis dalam sejarah masa lalu dimana Rasulullah s.a.w. menyebarkan agamanya, tetapi dalam kehidupan sekarangpun terbukti tentang kemajemukan hidup masyarakat. Séperti halnya di Indonesia juga dapat disebut sebagai masyarakat majemuk (plural) disebabkan hampir semua agama, khususnya agama-agama besar (Islam, Kristen, Hindu dan Budha) terwakili di Indonesia. Berikutnya dengan itu, masyarakat sering merujuk dengan perasaan bangga yang sulit disembunyikan kepada kadar toleransi keagamaan yang tinggi kepada bangsa kita. Bahkan tidak jarang sikap itu disertai sedikit banyak anggapan bahwa di dunia, dan sudah tentu Pancasila acapkali disebut sébagai salah satú bahan dasar, jika bukan yang terpenting bagi keadaan-keadaan positif itu (Nurcholis Madjid, 1992 : 177).

Dalàm menanggapi kemajemukan agama, M. Din Syamsuddin mengatakan bahwa kemajemukan agama adalah kenyataan yang tidak dapat diingkari mungkin merupakan "Sunnatullah" dalam proses pembiakan dan persebaran umat manusia. Proses globálisasi yang membara 
proses pluralisme atau pemajemukan dewasa ini menjadikan kemajemukan tersebut bertambah majemuk, seperti halnya kemajemukan agama, proses pemajemukan agama juga tidak bisa dielakkan. Proses ini bahkan dapat terjadi dalam satu tradisi keagamaan yang majemuk dikalangan umat satu agama. Proses sejarah membuktikan bahwá paham keagamaan ini dapat mentransformasi menjadi agama tersendiri. Banyak agamaagama kontemporer sesungguhnya merupakan "Sempalan" dari agama induk tertentu (Panjimas No. $771: 14$ ).

Sinyalemen-sinyalemen - yang tertuang dalam Al-Qur'an dan fakta-fakta yang dikemukakan oleh para pakar tentang pluralisme kehidupan manusia memberikan indikasi bahwa aspek-aspek perilaku sosial budaya produk manusia sangat mempengaruhi budaya Qur'ani. Oleh karena itu untuk menjaga kelestarian sosial budaya Islam maka setiap produk budaya manusia harus selalu dipayungi dengan budaya Qur'ani.

\section{Penciptaan Manusia dan Gagasan Al- Qur'an tentang Sosial Budaya.}

Apabila manusia ditinjau dari sudut pandang agama Islam, maka manusia adalah khalifah Allah di bumi. Makhluk yang bertugas mengurus bumi dengan seluruh isinya, dan berkewajiban memakmurkannya. Menurut kodratnya, manusia cinta kepada kesucian dan selalu cenderung kepada kebenaran. Tema-tema Al-Qur'an tentang penciptaan manusia ini banyak diungkap baik secara filosofis, tujuan dan arti kehidupan itu menuntut kepatuhan mutlak manusia, adalah pemenuhan dan realisasi kehendak Tuhan.
Manusia dilengkapi dengan unsur-unsur yang sangat esensial untuk menjalankan misi istimewanya sebāgai khalifah. Sebagai makhluk bermoral, manusia merupakan jembatan kosmis tempat lewat kehendak Illahi, dalam totalitas dan etika yang tinggi menembus ruang waktu dan menjadikannya aktual. Manusia juga dilengkapi akal dan kemampuan mengkonseptualisasikan, diberi petunjuk melalui wahyu Tuhan dalam terma-terma keutamaan moral. (Manzoor, 1991 : 64).

Unsur-unsur esensial yang melekaṭ pada diri manusia itu menjadikan status ke-khalifahan yang disandangnya dalam lingkup anugerah Allah yang sentral dan berimplikasi pada suatu otoritas untuk merancang bangunan masyarakat dan masa depannya. Berdasarkan pengertian tersebut, kiranya jelas bahwa khalifah adalah gagasan Al-Qur'an tentang kebudayaan.

Sedangkan bumi dengan berbagai fasilitas yang tersedia di dalamnya menjadi sarana sekaligus -alat dalam berkreasi untuk menemukan sesuatu yang bermanfaat bagi individu maupun lembaga-lembaga kemasyarakatannya. Di samping otoritas mutlak yang diberikan kepada manusia, mereka juga harus dapat mempertanggungjawabkan seluruh perbuatannya. Di dalam Al-Qur'an terdapat pernyataan "Apakah kàmu mengira bahwa Kami menciptakan kamu sia-sia, dan bahwa kamu tidak akan dikembálikan kepada Kami". (AI-Mu'minun, 115), mengingatkan manusia bahwa seluruh aktivitasnya yang merupakan menifestasi budaya harus dapat dikontrol berdasarkan kriterium nilai Ilahiyah. Dalam kaitan ini, Islam sarat dengan kandungan sistem nilai moral dan norma-norma yang dapat_dijadikan pilar 
pembentukan masyarakat yang beradab.

Pesan-pesan AI-Qur'an seperti menegakkan keadilan dalam dimensi politik, ekonomi, sosial, spiritual dan dimensi-dimensi lainnya, menunjukkan bahwa Al-Qur'an mampu, memotivasi manusia untuk berkarya sekaligus berkiprah dalam kehidupan menurut batasbatas etik tertentu untuk menjalankan transaksi kehidupan.

Menyimpang dari gagasan etik dan konsep-konsep eternal Al-Qur'an, individuindividu dan masyarakat akan kehilangan pegangan dan karenanya bertentangan dengan fitrahnya, sehingga aktivitas manusia dalam lingkungan dan masyarakat merupakan suatu cerminan dari kreasi yang secara utuh dapat dikategorikan menjadi suatu budaya yang erat kaitannya dengan kesadaran moral dan etika kebudayaan.

Di sini, pandangan mengenai budaya meliputi perilaku yang berwujud dalam pola aktivitas suatu masyarakat, dan budaya bentuk fisik material yang dihasilkan oleh kreatifitas individu atau kelompok masyarakat. Kedua bentuk budaya ini sesungguhnya bisa diukur dengan nilai pola interaksi sosial kelompok masyarakat, baik itu dalam bidang ekonomi, politik dan kesenian.

\section{Peranan Dakwah dalam Transformasi}

\section{- Sosial Budaya}

Dalam melaksanakan tugasnya selaku utusan Allah, Muhammad selalu menekankan ajaran moralitas keagamaan (Islam) dalam rangka menciptakan tatanan kolektivitas yang utuh dan harmonis. Doktrin yang ditawarkan adalah al-Furqan, pemisah antara yang baik dengan yang buruk. Paras dakwah yang ditampilkan oleh Nabi ini menunjukkan sikap arif dan bijaksana yang menempatkan beliau sebagai teladan yang baik.

Dalam kontek kebudayaan, interaksi dakwah dengan lingkungan sosial berkembang dua tipe pendekatan yang diametrical, yaitu pendekatan yang kompromis dan non kompromis. (Simuh, $1993: 6$ ). Tipe pendekatan non kompromis berdasarkan pada pengembangan nalar yang membedakan secara diameterik antara yang Islami dan yang tidak Islami. Istilahistilah diametrik seperti iman dan kafir, Islam dan Jahiliyah, tauhid dan musyrik adalah sarana untuk menarik garis pemisah (furqan) yang tegas dan diametrik antara yang Islami dan yang tradisi Sosial budaya masa jahiliyah yang sangat bertentangan dengan Islam. Ciri utama tipe pendekatan ini, kurang terbuka dan hanya dapat menerima unsur-unsur tradisi setempat atau yang bisa diintegrasikan dengan ajaran Islam. Dengan cara ini ajaran-ajaran agama tetap terjaga karena memang bertujuan ingin mendominasi atau mewarnai secara kental budaya-budaya yang ada.

Betapapun luhurnya tujuan dari tipe pendekatan non kompromis, namun dalam prakteknya sering kurang mendapat respon positif dari masyarakat, terutama mereka yang fanatik dan mempertahankan tradisi lama. Dengan latar belakang seperti inilah banyak konflik atau bahkan menimbulkan pertempuran fisik.

Karena bagaimanapun juga mendobrak sesuatu yang sudah mengakar dalam budaya masyarakat merupakan pekerjaan yang tidak ringan. Pada masa awal Islam, misalnya, sering terjadi ketegangan antara Rasulullah dan kaum muslimin dari satu pihak dengan elitiselitis Arab Quraisy yang sangat membela tradisi jahiliyah dari pihak lain. Demikian 
ini sering mengakibatkan tindakantindakan penindasan terhadap kaum muslimin yang pada masa itu secara kuantitatif jauh lebih kecil dibanding mereka yang menyembah berhala (musyrik).

Pendekatan non kompromis sesungguhnya bertujuan mempertahankan jati diri ajaran Islam. Oleh karena itu membutuhkan aktor dakwah yang sanggup memahami jiwa dan kepribadian ajaran AlQur'an, dan memiliki pandangan kritis dan dinamis terhadap lingkungan seni dan sosial budaya yang dihadapinya. Sehingga mampu membedakan hal-hal yang Islami dengan yang tidak Islami. Jati diri ajaran Islam tidak tergantung pada sosial budaya di dalam suatu daerah tertentu. Untuk itulah dalam pelaksanaan dakwah, terutama keluar menghadapi masyarakat primitif hanya akan-berjalan mulus dengan. mendahulukan amar (perintah) terhadap hal-hal yang ma'ruf dan mengemudikan nahi (larangan) terhadap hal-hal yang mungkar, sebagai taktik pentahapan proses untuk sementara waktu. Tipe pendekatan non kompromis, dengan demikian, tetap relevan untuk menciptakan seni atau memperhalus seni budaya setempat ke arah yang positif yang dapat dimanfaatkän untuk mengembangkan agama.

Pendekatan tipe kompromis ini sangat dominan dalam sejarah penyebaran agama Islam. Pada kompromis ini berarti ajaran Islam dipertemukan atau dipadukan dengan tradisi budaya lama yang memiliki jati diri yang berbeda atau bahkan mungkin berlawanan. Dengan perpaduan ini tentu membentuk sinkritis yang menyimpang dari jati diri ajaran Islam asali (awali). Para pakar muslim mengasumsikan bahwa munculnya pendekatan ini lebih disebabkan karena faktor ketidaktahuan terhadap jati diri Islam asali. Yaitu jati diri ajaran Islam yang dipahami dan diamalkan oleh Nabi dan sahabat pada periode awal Islam. Konsep imamah, misalnya, yang dikembangkan oleh aliran Syi'ah menurut dugaan berasal dari tradisi budaya suku Arab bagian selatan (yaman) dan warisan kerajaan Persia purba yang mendewadewakan sang raja. Pemitosan para Imam atau pimpinan agama berasal dari pendewaan tersebut, kemudian dijadikan pisau analisis untuk memahami dan menafsirkan ajaran Islam.

Berkembangnya konsep imamah yang demikian dalam tradisi Syi'ah berarti mereka merubah sistem kepemimpinan rasional dalam Islam dengan ulama sebagai pemuka agama sesudah zaman $\mathrm{Nabi}$, menjadi sistem kepemimpian yang kharismatik dengan-para imam sebagai pemegang otoritas di atas para ulama. (Simuh, 1993).

Namun demikian; pendekatan tersebut sangat prospektif bagi pengembangan agama Islam. Karena nilainilai ajaran Islam tidak rigit sehingga selalu terbuka untuk menyedap kreasi-kreasi pemikiran baru budaya. Dan budaya inipun akan mencuat berkat dukungan dan penyerapan unsur-unsur kerohanian dan etika ke-Islaman. Strategi kebudayaan yang dijalankan oleh aktor dakwah adalah tidak lain upaya menyelenggarakan unsur-unsur ajaran Islam dengan warisan budaya komunitas dalam suatu daerah.

Masyarakat Muslim dan Kebudayaan
Kontemporer
Dalam Islam tidak ada pertentangan
antara etika yang terinternalisasi dengan
hukum yang tereksternalisasi, antara niat 
yang terssembunyi dengan tindakantindakan nyata. (Manzoor, $1991: 64$ ). Oleh sebab itu, nilai kebudayaan bagi komunitas muslim yang merupakan hasil kreasi dan produkstivitasnya adalah yang mendasar dari masyarakat itu sendiri. Islam menuntut bahwa masyarakat perlu moralitas dan tuntunan-tuntunan komitmen relegius. Nilai-nilai agung ini menjadi kontrol aktivitas manusia, termasuk memberi arahan dalam pembentukan budaya. Jadi pemanfaatan alam semesta dengan etika transendental menjadi tujuan utama manusia.

Dan nilai-nilai yang bersumber dari Al-Qur,an dan Sunnah satu-satunya alternatif pilihan dalam era globalisasi yang mendunia ini dimana nilai-nilai yang bersumber dari luar ajaran Islam sudah tidak mampu menyelamatkan manusia dari krisis nilai yang sangat kontras dengan tujuan penciptaannya.

Namun demikian, dalam era globalisasi ini dimana pembangunan merupakan usaha aplikatif atas penemuanpenemuan ilmu pengetahuan dan teknologi; sebagai salah satu manifestasi kebudáyaan terdapat dua kecenderungan para pemikir muslim. Pertama, kelompok modernis berkeyakinan dan bersikap optimis yang realis. Artinya; mereka menerima dan membuka diri dengan penuh gairah pengaruh ilmu dan teknologi barat sebagai sarana yang paling ampuh untuk menyegarkan dan mendinamisir kemurnian pemahaman agama mereka. Pandangan ini cukup realistis karena dengan mengawinkan Islam dengan pendekatan dan analisis ilmiah hasil pemikiran barat modern pemurnian pemikiran Islam yang dinamis kritis bisa dihidupkan kembali. Kedua, kelompok revitalis, mengembangkan sikap optimis yang romantisme: Mereka bêrkeyakinan bahwa Islam justru merupakan alternasi bagi kemajuan peradaban barat.

Mereka berkeyakinan dan optimis, apabila segala-galanya telah dikembalikan pada jati diri Islam tentu otomatis akan beres. Sikap optimistis ini, kemudian memunculkan ide islamisasi ilmu; ekonomi, masyarakat dan lain sebagainya.

Lepas dari sikap tersebut di atas, jiwa ajaran Islam yang terkandung dalam pesan-pesan Al-Qur'an dan sunnah adalah sebagai bentuk dan nilai yang paling sesuai dengan semangat zaman modern. Islam telah menklaim dirinya sebagai aliran komprehensip dan rahmatan bagi seluruh makluk. sudah barang tentu mampu menumbuhkan satu tradisi nilai baru yang relevan dengan perkembangan zaman. Dalam prespektif ini, Islam ditempatkan sebagai satu sistem lengkap dan sempurna dalam proses modernitas masyarakat. Dan eksistensinya harus ditonjolkan secara kreatif dan fungsional sehingga mampu beraklarasi dengan perubahan arus modernisasi bidang-bidang sosial, politik, pengembangan alat-lat produksi dan teknologi, demikian juga di bidang pemikiran dan kebudayaan.

\section{Penutup}

Dalam masa global yang sudah mendunia ini, dimana pengaruh budaya asing telah menimbulkan konflik nilai sebetulnya akan menempatkan umat Isläm pada posisi delematis. Bukankah Islam karena sosoknya yang Ilahiyah dan ideal mampu membangkitkan inti kebebasan jati diri manusia yang mandiri dan luhur. Islam memandang secara menyeluruh aspekaspek filsafat, spiritual, dan pandangan- 
pandangan moral. Dengan demikian problema umat dalam lingkaran konflik nilai bisa diselesaikan melalui interpretasi dahwah ke dalam pengertian tranformasi budaya dalam pengertian yang dinamis, namun berakar pada nilai-nilai Qur'ani.

\section{Daftar Bacaan}

Al-Faruqi, Ismail R, Isiam dan Kebudayaan, alih bahasa Yustiono, Mizan, tt, hal. 7. Manzoor, S. Parvez, Lingkungan dan nilai-nilai dalam prespektifIslam, (Jurnal ilmu dan
Kebudayaan Ulumul Quran, No. 9, vol. II, 1991), hal. 64

Nurcholish Madjid, DR Islam Doktrin dan Peradaban sebuah Telaah Kritis tentang Keimanan, Kemaniusiaan dan Kemoderenan, Jakarta : Yayasan Wakaf paramadina, 1992.

Panjimas, Nomor 771, tahun XXXV

Simuh, 'Dr, Interaksi Islam dan Kebudayaan Tradisional, (Jurnal Penelitian Agama, no. 3 Januari-April 1993, Balai penelitian P3M IAIN Sunan kalijaga Yogyakarta) hal. 6. 